Creative Commons User License: CC BY-NC-ND

Abstracted by: EBSCOhost, Electronic Journals Service (EJS), Google Scholar, Journal Seek, Scientific Commons,

Food and Agricultural Organization (FAO), CABI and Scopus

http://eoi.citefactor.org/10.11226/v23i2
Journal of Agricultural Extension

Vol. 23 (2) April, 2019

ISSN(e): 24086851; ISSN(Print); 1119944X

http://journal.aesonnigeria.org

http://www.ajol.info/index.php/jae

Email: editorinchief@aesonnigeria.org

\title{
The Effect of Agglomeration on Profits and Price Efficiency in Laying Chicken Farming Enterprises in Payakumbuh Production Central Area of Lima Puluh Kota Regency, West Sumatera, Indonesia
} https://dx.doi.org/10.4314/jae.v23i2.7

\author{
Deltri Apriyeni \\ Department of Economic Education \\ STKIP PGRI of West Sumatera, Indonesia \\ E-mail : deltri.apri@gmail.com., Phone : +6282386635128
}

\author{
Sjafrizal Sjafrizal \\ Faculty of Economy \\ University of Andalas, Indonesia \\ E-mail : sjafrizal17@gmail.com, Phone : +628126620051
}

\section{Jafrinur Jafrinur}

Faculty of Animal Husbandry

University of Andalas, Indonesia

E-mail : jafrinur@yahoo.com, Phone : +628126791138

\section{Melinda Noer}

Faculty of Agriculture

University of Andalas, Indonesia

E-mail : melindanoer@yahoo.com, Phone: +62811225407

\begin{abstract}
This study analysed the effect of agglomeration on profits, and price efficiency. This study was carried out in and outside the Production Central Area (PCA) of Payakumbuh. Sixty-seven breeders in Payakumbuh PCA and 67 breeders outside Payakumbuh PCA were involved. Multiple linear regression was used for analysis. The results showed that there were two agglomeration profits in PCA: large scale economies (SE) and localization economies (LE). Urbanization economies (UE) were not found. The agglomeration profits had a significant effect on price efficiency. The difference in business location between PCA and outside PCA had no significant effect. The establishment of a PCA should take into account the agglomeration profits, which can be profitable for entrepreneurs with lower production and transportation costs due to the use of shared facilities. It is important to equip the PCA with supporting infrastructure to develop livestock business with the aim to reduce production costs, and make output competitive.
\end{abstract}

Keywords: Agglomeration profits, price efficiency, production central area

\section{Introduction}

Each region of a country, city, or regency experience different growth rates. The speed of interregional growth gave rise to a theory of imbalances in inter-regional growth. The theory of growth pole by identifying the region that grow faster (growing point) and the region that grow slowly (lagging region). The development of a region is closely related to the potential resources available in the region, whether it is natural resources or human resources. If these two potentials 
Creative Commons User License: CC BY-NC-ND

Abstracted by: EBSCOhost, Electronic Journals Service (EJS), Google Scholar, Journal Seek, Scientific Commons,

Food and Agricultural Organization (FAO), CABI and Scopus
Journal of Agricultural Extension

Vol. 23 (2) April, 2019

ISSN(e): 24086851; ISSN(Print); 1119944X

http://journal.aesonnigeria.org

http://www.ajol.info/index.php/jae

Email: editorinchief@aesonnigeria.org

http://eoi.citefactor.org/10.11226/v23i2

exist in one area, then most likely this region will grow and develop faster compared to the regions

that lack of these two resources. In addition, access to transportation, information, credit, entrepreneurship skills, various public facilities, and adequate supporting infrastructure facilities also determine the acceleration of growth in an area (Sjafrizal, 2018; Tarigan, 2018; Musa, 2018; Nwabeze, 2017; Salau, 2017).

From geographical point of view, the location and the natural conditions of Lima Puluh Kota Regency are very supportive for the development of the agriculture, livestock, plantation and fisheries sectors. In order to make a growth pole, it is introduced the concept of leading industries, and large propulsion companies are included in the leading industries which dominate other economic units (Dobrescu et.al., 2014; Bere et.al., 2015; Dobrescu et.al., 2015, Arsyad, 2016). The agricultural sector, the livestock sub-sector, particularly laying chicken farms, can be used as leading industries because these two sectors develop and grow well. The agricultural sector, especially livestock, is a sector that dominates the business of rural communities, especially in Lima Puluh Kota Regency, West Sumatra Province. The contribution of the agricultural, fishery, and forestry sectors towards the Gross Domestic Regional Product (GDRP) in 2016 was 37.26\% (Central Bureau of Statistics, 2016). Agglomeration profits are the benefits that come when firms and people locate near one another together in cities and industrial clusters. Agglomeration in an industry was supported by the location and natural superiority (Carlino et.al., 2014). The developed area has a higher economic potential.

Breeders take two different locations, i.e. inside and outside production central area, for chicken farms in Lima Puluh Kota District. Breeders in the PCA are geographically located nearly and in groups, while those outside the PCA are located separately and far apart from one location to another. In the PCA, it is easier to obtain the production input materials because the traders of the materials are close to the farmer's business location. Meanwhile, it is difficult to obtain the materials if the location is outside PCA. The importance of location in production is in accordance with the opinion of (Qing, (2012) ; Soylemezoglu, (2014) and Kornita, (2017)

This study investigated the reasons why business in PCA grow and develop faster, agglomeration profits for business in PCA, and the influence of agglomeration profits on price efficiency in two different business locations.

\section{Methodology}

Lima Puluh Kota Regency is a district of West Sumatra Province, Republic of Indonesia, with a geographical location at 0013'60.00"N and 100037'58.80"E. (Central Bureau of Statistics, 2016). The population of this study was made of laying chicken breeders in PCA of Payakumbuh and outside PCA. The 67 breeders in Payakumbuh Subdistrict were all involved. Similarly, 67 breeders outside the PCA were used. The three sub-districts outside the PCA were Luhak District, Lareh Sago Halaban District and Situjuah Limo Nagari District. Questionnaires and in-depth interviews while use in collecting primary data while secondary data were obtained from relevant agencies, which provided information on regional characteristics of the region. 
Creative Commons User License: CC BY-NC-ND

Abstracted by: EBSCOhost, Electronic Journals Service (EJS), Google Scholar, Journal Seek, Scientific Commons,

Food and Agricultural Organization (FAO), CABI and Scopus

http://eoi.citefactor.org/10.11226/v23i2
Journal of Agricultural Extension

Vol. 23 (2) April, 2019

ISSN(e): 24086851; ISSN(Print); 1119944X

http://journal.aesonnigeria.org

http://www.ajol.info/index.php/jae

Email: editorinchief@aesonnigeria.org

Table 1: Number of breeders, and egg production in Lima Puluh Kota Regency 2016

\begin{tabular}{lcrr}
\hline Districts & $\begin{array}{c}\text { Number of } \\
\text { breeders }\end{array}$ & $\begin{array}{c}\text { Population } \\
\text { of laying } \\
\text { chicken } \\
\text { eggs }\end{array}$ & $\begin{array}{c}\text { Number of } \\
\text { egg } \\
\text { production } \\
\text { per year }\end{array}$ \\
\hline Payakumbuh PCA & 67 & 1.503 .255 & $11.590 .096,05$ \\
Akabiluru & 13 & 178.580 & $1.376 .851,80$ \\
Luak & 17 & 349.600 & $2.695 .416,00$ \\
Lareh Sago Halaban & 43 & 536.525 & $4.136 .607,75$ \\
Situjuah Limo Nagari & 15 & 271.440 & $2.092 .802,40$ \\
Harau & 48 & 560.500 & 4.321 .455 .00 \\
Guguk PCA & 22 & 677.000 & $5.219 .670,00$ \\
Mungka PCA & 17 & 772.515 & $5.956 .090,65$ \\
Suliki & 7 & 128.775 & $992.701,05$ \\
Bukit Barisan & 1 & 455 & $3.508,05$ \\
\hline Total & & & \\
\hline Soura & & & \\
\hline
\end{tabular}

Source: West Sumatera Livestock and Animal Health Department, 2016.

\section{Operationalization of Variables}

The variables used in the research were based on calculation method of agglomeration profits from Isard (1960) as stated by (Sjafrizal, 2018). The independent variable in the research was agglomeration profits which was divided into three; large scale economies (SE)i with production costs as indicators; localization economies (LE)i with transportation costs of input and output production as indicators; and urbanization economies (EU)i, the indicator was the facility used jointly by breeders in PCA. The difference in business location (PLU) i was a dummy variable. Coded 0 for locations outside PCA and code 1 for locations in PCA. Meanwhile the dependent variable was price efficiency with the cost of output production (price per egg) as indicator. To measure the agglomeration profits, these following formulas can be used: 1) Large scale economies SEi was used as a comparative cost method. The formula is as follows: $\mathrm{SEI}_{\mathbf{l}}=\mathrm{AC}_{0}$ $A C I . S E>0$ or $A C_{0}>A C$ । means the selection of business locations in the location of the PCA will be profitable and vice versa. $A_{0}$ is the average cost if it is located outside the area and $A C_{I}$ is the average cost if it is located within the area. 2) Localization economies LEi are profits in the form of cost savings as well as of raw materials produced, which arise because they are concentrated with other related companies. It can be measured by the following formula: $L E_{I}=T R_{0}-T R I$. LEI> 0 or $T R_{0}>T R I$ means that the choice of business location in a PCA is more profitable because the amount of transportation costs incurred by the company located outside the PCA is greater than the company that located within the PCA. 3) Urbanization economies (EU) i, are the profits arised 
Creative Commons User License: CC BY-NC-ND

Abstracted by: EBSCOhost, Electronic Journals Service (EJS), Google Scholar, Journal Seek, Scientific Commons,

Food and Agricultural Organization (FAO), CABI and Scopus
Journal of Agricultural Extension

Vol. 23 (2) April, 2019

ISSN(e): 24086851; ISSN(Print); 1119944X

http://journal.aesonnigeria.org

http://www.ajol.info/index.php/jae

Email: editorinchief@aesonnigeria.org

http://eoi.citefactor.org/10.11226/v23i2

from the use of facilities in an area jointly, such as; electricity, warehousing, telephone, drinking water and other utilities that support business operations. It can be calculated by using the following formula: $U E_{I}=\left\{(C / U)_{\circ}-(C / U) I\right\}$. UEI> 0 or $(C / U)_{\circ}>(U / C)$ I means the choice of business locations within the PCA is more profitable because the amount of facility usage costs incurred by the company located outside the KSP is greater compared those within PCA, and vice versa. i means breeder, $1 \ldots \mathrm{n}$.

\section{Effect of Agglomeration Profits on Price Efficiency}

To measure the effect of price efficiency on the benefits of agglomeration profits, multiple linear regression was used with model as follows:

$$
Y=\beta o+\beta \text { I (SE ) } i+\beta 2 \text { (LE) } i+\beta 3 \text { (UE) } i+\beta 4(P L U) i+e i
$$

where: $Y=$ price efficiency (dependent variable), the independent variable consists of: $\beta$ o $=$ constant value, $\beta 1=$ coefficient of regression value (SE) i, $\beta 2=$ coefficient of regression value (LE) i, $\beta 3=$ coefficient of regression value (UE) i, $\beta 4=$ regression value coefficient (PLU) i, (SE) i, $=$ large scale economies, (LE) $\mathrm{i}=$ localization economies, $(E U) \mathrm{i}=$ urbanization economies $\mathrm{e}=$ error (e), i = broiler breeder, i ..... n.

\section{Results and Discussions}

\section{Agglomeration Profits}

The average production costs (SE)i outside PCA and within PCA were Rp. 979,00 per egg and Rp. 893,00 per egg, respectively. The difference in average production costs in both locations was Rp. 86,00. This is called as the estimated agglomeration profit of Rp. 86,00 per egg. The transportation costs (LE)i outside PCA and within PCA were Rp 30.00 per egg and Rp. 20,00 per egg, accordingly. The difference in transportation costs for both locations was Rp. 10,00 per egg. The cost difference was an estimate of the agglomeration profit from the difference in average transportation costs at both business locations.

Table 2: Estimated Agglomeration Profits in Payakumbuh Production Central Area (PCA)

\begin{tabular}{llccc}
\hline $\begin{array}{l}\text { Agglomeration } \\
\text { Profits }\end{array}$ & $\begin{array}{c}\text { Calculation } \\
\text { Method }\end{array}$ & $\begin{array}{c}\text { Outside } \\
\text { PCA }\end{array}$ & $\begin{array}{c}\text { Within } \\
\text { PCA }\end{array}$ & $\begin{array}{c}\text { Estimation } \\
\text { Agglomeration Profits } \\
\text { (outside PCA- within } \\
\text { PCA) }\end{array}$ \\
\hline $\begin{array}{l}\text { Large Scale } \\
\text { Economies }\end{array}$ & $\begin{array}{l}\text { Average of } \\
\text { production cost } \\
\text { per output }\end{array}$ & 979 & 893 & 86 \\
$\begin{array}{l}\text { Lecalization } \\
\text { Transportation }\end{array}$ & 30 & 20 & 10 \\
$\begin{array}{l}\text { Economies } \\
\text { (LE)i }\end{array}$ & cost per output & & & \\
$\begin{array}{l}\text { Urbanization } \\
\text { Economies }\end{array}$ & $\begin{array}{l}\text { Cost of shared } \\
\text { facilities }\end{array}$ & - & - & - \\
\hline
\end{tabular}

The advantage of PCA is obtained when there are agglomeration profits for business actors in the region rooted in three pillars: large scale economies (SE) i, localization economies (LE) i, 
Creative Commons User License: CC BY-NC-ND

Abstracted by: EBSCOhost, Electronic Journals Service (EJS), Google Scholar, Journal Seek, Scientific Commons,

Food and Agricultural Organization (FAO), CABI and Scopus
Journal of Agricultural Extension

Vol. 23 (2) April, 2019

ISSN(e): 24086851; ISSN(Print); 1119944X

http://journal.aesonnigeria.org

http://www.ajol.info/index.php/jae

Email: editorinchief@aesonnigeria.org

http://eoi.citefactor.org/10.11226/v23i2

urbanization economies (EU) i through savings in production costs, transportation costs and shared facilities in the region. The following table illustrated the data of research in the form of calculation of the estimated agglomeration profits in PCA.

There were agglomeration profits in PCA. Among the three pillars of the agglomeration profits, there were only two economies: large scale economies (SE)i and localization economies (LE)i, while the third agglomeration profits were: urbanization economies (EU)i, which were not in the PCA. Based on the comparison of production costs between business locations within PCA and outside PCA, there was a difference in production costs of Rp.86,00 per egg (estimation of agglomeration profits). It can be said that it is more profitable for breeders within the PCA because of savings in production cost. Savings in production costs were caused by the business factors run by breeders who are more established and can afford to buy inputs in large quantities. Consequently, the purchase price of production inputs was lower compared to breeders outside the PCA who bought production input materials at a higher cost.

Breeders located in PCA generally bought feed ingredients, medicines, vitamins/minerals directly to feed factories located in Medan city (North Sumatera), Padang city, and Lampung city. Large amounts of collection and good relationships built for years with the company profited to breeders for the payments because they were given a grace period of up to one month at a lower price when compared to breeders who take inputs to traders or poultry shops located in PCA. In addition to the purchase of inputs directly to the factory, breeders in the PCA can buy feed at the poultry shop at a lower cost compared to breeders outside the PCA. Breeders in PCA benefit because the location is close to the seller and is not burdened by high transportation costs when compared to breeders outside the PCA. On the other hand, breeders outside PCA bought inputs from seller in PCA with certain additional costs, especially when buying non-cash. The purchase of non-cash inputs is calculated by adding a number of interest on debt, depending on how long the payment can be made by the farmer. Poultry shop prefers to open a business in the PCA because it is close to the farmer as a buyer.

The further agglomeration profits found in PCA was the localization economies (LE)i. From the estimation results of localization economies (LE)i, with an indicator of the inputs and outputs of transportation cost, the profit of Rp. 10.00 per egg was obtained. It can be explained that breeders in Payakumbuh PCA were more economical or have lower transportation costs in comparison with breeders outside the PCA.

The difference in transportation costs was related to the distance between the breeder's business location from the production sellers located in the PCA. The purchase of production input materials directly to the factory with a large amount also reduced the transportation costs compared to purchase from production sellers in the PCA. Likewise, the transportation costs of output production, the full capacity of transport with a large amount resulted in a lower costs per egg. The large amount and sustainable output production with loyal customers caused the livestock business in Payakumbuh PCA to be more efficient in transportation costs.

The third agglomeration profits were urbanization economies (EU)i. The indicators of the use of production facilities jointly aimed to save and facilitate the production process were not found in Payakumbuh PCA. Breeders in Payakumbuh PCA only utilized the existing facilities in accordance with their own. Facilities owned by breeders such as warehousing, electricity, clean water, corn grinders, were used personally. Based on the interview results with breeders, there were no facilities used jointly. Breeders with a large scale business have complete facilities for their own 
Creative Commons User License: CC BY-NC-ND

Abstracted by: EBSCOhost, Electronic Journals Service (EJS), Google Scholar, Journal Seek, Scientific Commons,

Food and Agricultural Organization (FAO), CABI and Scopus
Journal of Agricultural Extension

Vol. 23 (2) April, 2019

ISSN(e): 24086851; ISSN(Print); 1119944X

http://journal.aesonnigeria.org

http://www.ajol.info/index.php/jae

Email: editorinchief@aesonnigeria.org

http://eoi.citefactor.org/10.11226/v23i2

use. Whereas breeders who do not have a corn milling machine pay rent to breeders who owned the machine. Another study which found the same result and supported the result of this research was conducted by Kornita (2017), which stated that breeders in Mungka PCA used their own production facilities. Urbanisation economies were not found in the research location (Kornita, 2017).

\section{Effect of Agglomeration Profits and Business Locations on Price Efficiency}

Based on result of Table 3 , the constant value $(\beta 1)$ of 1,013 means if the agglomeration economies of large scale economies or (SE)i, $(i=$ broiler breeder, $i$..... $n$ ), increases by 1 point, it will result in an increase in production costs if located outside the PCA compared to those located within PCA, there will be a price difference of 1,013 Rupiah per unit of output, assuming other variables are considered constant (cateris paribus). Large scale economies or (SE) i are positively related to the difference in price $(\mathrm{PH}) \mathrm{i}$, within the PCA and outside the PCA.

Constant value $(\beta 2)$ of 3,747 means if the agglomeration economies of localization economies (LE) i increases by 1 point, it will result in an increase in transportation costs if it is located outside the PCA compared to those located in PCA, there will be a price difference of 3.747 rupiah per unit of output, assuming other variables are considered constant (cateris paribus). Localization economies (LE) i, are positively related to the difference in price $(\mathrm{PH}) \mathrm{i}$, within PCA and outside PCA.

Constant value $(\beta 4)$ of 0.253 means if the difference of business location variable (PLU) $i$, increase by 1 point, it will result in a change in business location away from PCA, there will be a difference in price $(\mathrm{PH}) \mathrm{i}$, between location within and outside the PCA of 0.253 Rupiah per unit of output, assuming other variables are considered constant (cateris paribus). The location difference (PLU) i, is positively related to the difference in price $(\mathrm{PH}) \mathrm{i}$. Study conducted by Arman (2017) strengthened the results of this study, which stated that the farmers within the public core plantation were more efficient in producing than the farmers outside the core plantation. The agglomeration profits generated from the public core plantation systems apparently affected the price and determined the competitiveness of palm oil products on the market (Arman, 2017).

Table 3: Causative factors of price efficiency

$$
\text { Price differentials }
$$

\section{Unstandardize \\ d Coefficients}

\begin{tabular}{|c|c|c|c|c|}
\hline Model & B & Std. Error & Beta & $t$ \\
\hline 1 (Constant) & $-11,274$ & 32,631 & & $-0,345$ \\
\hline $\begin{array}{l}\text { Large Scale } \\
\text { Economies } \\
\text { (SE)i }\end{array}$ & 1,013 & 0,370 & 0,307 & $2,737^{\star}$ \\
\hline $\begin{array}{l}\text { Economies } \\
\text { (LE)i } \\
\text { Difference in } \\
\text { bussines } \\
\text { location } \\
\text { (PLU)i }\end{array}$ & 3,747 & 6,111 & 0,005 & $3,014^{\star}$ \\
\hline
\end{tabular}

${ }^{*} \mathrm{P} \leq 0.05$ 
Creative Commons User License: CC BY-NC-ND

Abstracted by: EBSCOhost, Electronic Journals Service (EJS), Google Scholar, Journal Seek, Scientific Commons,

Food and Agricultural Organization (FAO), CABI and Scopus
Journal of Agricultural Extension

Vol. 23 (2) April, 2019

ISSN(e): 24086851; ISSN(Print); 1119944X

http://journal.aesonnigeria.org

http://www.ajol.info/index.php/jae

Email: editorinchief@aesonnigeria.org

The influence of large scale economies or (SE)i and localization economies or (LE)i were very significant to price changes (PH)i. Breeders in Payakumbuh PCA have low production cost and transportation costs compared to breeders outside PCA. Thus, breeders were able to reduce the selling price of production output and laying chicken farming business was more efficiently carried out within the PCA. From the point of view of agglomeration economies, based on the two variables, the role of PCA was able to provide agglomeration economies for breeders. In other words, breeders were more profited by occupying business locations in PCA. For a greater agglomeration profits, it needs to be improved according to the ideal PCA conditions. The difference in business location variable (PLU)i had no significant effect on the price difference $(\mathrm{PH})$ i. If breeders outside Payakumbuh PCA survive at prices which were different significantly from price in the PCA, the egg production will be less competitive in the market. Breeders prefer to reduce business profits thus there was no significance in price difference compared to output price in Payakumbuh PCA although the costs incurred by breeders outside PCA were greater than those within PCA. The breeders outside the PCA were at risk because of the higher production and transportation costs while the selling price cannot be too different compared to the selling price in the PCA. Kornita (2017) also found that the breeders outside PCA have a higher production and transportation costs in comparison with the breeders within PCA.

\section{Conclusions and Recommendations}

There were only two elements of agglomeration profits in Payakumbuh PCA; large scale economies (SE) i and localization economies (LE) i, while urbanization economies (EU) i were not found. Breeders were more profitable to work in PCA because the production and transportation costs incurred by breeders were lower. The agglomeration profits in Payakumbuh PCA had a significant effect on the efficiency of broiler egg prices. Prices in Payakumbuh PCA became more competitive in the market. The difference in business location (PLU) i did not significantly affect price differences.

It is necessary to create facilities that can be used together in Payakumbuh PCA to increase the agglomeration profits. It needs support from various government agencies involved as policy makers. Breeders as the main actors in running a business will not be able to create it themselves without the support of various parties who are competent in this business. The existence of supporting facilities and infrastructure in the PCA must be the main benchmark for the acceleration of the progress of the PCA, such as road, bridge repairs, and street lighting to the PCA, which must be in a good condition. To overcome differences in the selling price of eggs between businesses within PCA and outside PCA, it is necessary to create institutions at the level of breeders who are able to bridge prices, such as by forming a joint cooperative engaged in marketing egg products, providing input materials at low prices and handling the selling price of eggs for both PCAs.

\section{References}

Arman, I. (2017). Development of Competitive Palm Oil Public Core Plantation. Postgraduate Dissertation, Andalas University, Padang, Indonesia.

Arsyad, L. (2016). Introduction to Regional Economic Development Planning. Yogyakarta: BPFE.

Central Bureau of Statistics of Lima Puluh Kota Regency (2016). Statistic of Lima Puluh Kota Regency 2016. ISSN : 1858-0955. 
Creative Commons User License: CC BY-NC-ND

Abstracted by: EBSCOhost, Electronic Journals Service (EJS), Google Scholar, Journal Seek, Scientific Commons,

Food and Agricultural Organization (FAO), CABI and Scopus
Journal of Agricultural Extension

Vol. 23 (2) April, 2019

ISSN(e): 24086851; ISSN(Print); 1119944X

http://journal.aesonnigeria.org

http://www.ajol.info/index.php/jae

Email: editorinchief@aesonnigeria.org

Bere, R.C. and Silvestru, C.I. (2015). 'On Growth Pole from EU Countries in The Framework of Europe 2020' Procedia Economic and Finance, Science Direct, Elsevier.

Carlino, G and R. Kerr, W. (2014). Agglomeration and Innovation, Handbook of Regional and Urban Economics, Vol. 5A and 5b.

Dobrescu, E.M. and Dobre, E.M. (2014). 'Theories Regarding The Role of The Growth Poles in The Economic Integration' Procedia Economics and Finance. ScienceDirect. Elsevier.

Dobrescu, E.M. and Dobre, E.M. (2015). 'Shanghai an Important Growth Pole of China's and for The Planet' Procedia Economics and Finance. ScienceDirect. Elsevier.

Kornita, S.E.(2017).Agricultural Development with a New Approach : Case Studies in the Poultry Production Central Area in Mungka Sub-District Lima Puluh Kota Regency. Postgraduate Dissertation, Andalas University, Padang, Indonesia.

Musa, K., Van, N.P., \& Retief,C.P. (2018). 'Challenges of contract farming among small-scale commercial vegetable breeders in Eastern Cape South Africa', Journal of Agricultural Extension, 22 (3).

Nwabeze,G.O., Ibeun,B.A., Faleke, S.,1., Omeje,J.E., Belonwu,N.E., Igene, C.A., Ogbonna, K., Nwanjoku, V.A. \&Ighoro, A. (2017). 'Information needs of fish-feed entrepreneurs in Kainji Lake Basin Nigeria', Journal of Agricultural Extension, 21 (3).

Qing, Z. (2012). 'The Research on Influence of Industrial Cluster on Regional Economic Development' IERI Procedia 3, pp206-212

Salau, E.S., Adua, M.M., Maimako, M.B \& Alanji, J. (2017). 'Entrepreneurship skills of small and medium scale poultry breeders in Central Agricultural Zone of Nasarawa State Nigeria', Journal of Agricultural Extension, 21 (3).

Sjafrizal, S. (2018). Regional Economic Analysis and Its Application, Jakarta: PT. Rajawali Pers.

Soylemezoglu. E , Dorukb, OT (2014). 'Are Clusters Efficient For The Relation Between Milk Production And Value Added Per Capita In Regional Level? An Empirical Assessment'. Elvesier CC-BY-ND License.

Tarigan, R. (2018).Regional Economy: Theory and Application, Jakarta: Bumi Aksara 